\title{
A new study of dye-sensitized solar cell from the extract of leaf, fruit, and mix of Mimosa pudica Linn
}

\author{
Iswadi I. Patunrengi ${ }^{1}$, Aisyah ${ }^{2}$, Sahara ${ }^{3}$, Nurul Fuadi ${ }^{4}$, Ardian $^{5}$, Mu'arif $^{6}$ \\ 1,3,4,5,6 Department of Physics, Faculty of Science and Technology, Universitas Islam Negeri \\ Alauddin Makassar, Indonesia. 92113 \\ ${ }^{2}$ Department of Chemistry, Faculty of Science and Technology, Universitas Islam Negeri \\ Alauddin Makassar, Indonesia. 92113 \\ \{wadi.phys.dept@uin-alauddin.ac.id¹, aisyah@uin-alauddin.ac.id²\}
}

\begin{abstract}
Dye-sensitized solar cells have been massive attention research because they are easy in fabrication, low-cost, sustainable, abundant material dye sources and high efficiency in power energy conversion. The natural dye that was extracted from Mimosa pudica Linn is potential to be used as a sensitizer for Dye-Sensitized Solar Cell. In this work, the dyes were extracted from three parts of plants; leaves, flowers, and the mix. $\mathrm{TiO} 2$ was used as the active material for semiconductor and applied by using the Doctor Blade method. Testing cells and the measurement of the voltage and the current were done outside under the sun irradiation. The UV Vis spectra of the dyes indicated that the absorption of the three samples shows significant absorptions in quite similar wavelengths, approximately $665 \mathrm{~nm}$. The DSSC cells had $0.16 \% ; 0.12 \% ; 0.01 \%$ of conversion energy efficiency for flowers, leafs and mix respectively. These results indicated that the dye which is extracted from the flower of Mimosa pudica Linn is higher among all extracts.
\end{abstract}

Keywords: Dye sensitized solar cell, Natural dye, PCE, Efficiency, Outdoor sun illuminated.

\section{Introduction}

Photovoltaics (PV) is a method to produce electricity from the sun. The direct current electricity can be produced by using semiconductor material. In fact, the photovoltaics system namely solar power consist of a number of solar cells. Most of the PV used today are based on Silicon technology with good stability and efficiency. However, it is high-cost production. Thin film technology had been presented to decrease the cost production and still under developing with mix (hybrid) organic-inorganic PV[1]. CIGS (CuInGaSe2), CIGS with concentrator, CdTe, amorphous Si: $\mathrm{H}$ (stabilized) and nano-micro-poly-Si are the example of the thin film solar cell. The low cost and best efficiency solar cells that presented in 1991 is based on dye-sensitized by Gratzel [2]. The last research showed that this type of solar cells obtain efficiency $11.9 \pm 0.4 ; 10.7 \pm 0.4$ and $8.8 \pm 0.3$ respectively for dye cell, mini-module, and submodule [3].

There was some research reported about DSSC with varying results, some of them are higher [4]-[6], moderate [7]-[9] and poor [10] power conversion energy (PCE) efficiency. The amounts of dyes from parts of plants' extract also varied [11] by different methods [10]-[18]. Furthermore, some research also reported changes in the characteristics of material such as 
doping a new material [17], [19]. The effect of some manipulations on the electrolytes [20], impact of photoelectrode thickness [21], modified counter electrode [16], and optimization of ITO glass [22] were also reported.

The main objective of this research is to study the efficiency of DSSC from extract dyes of Mimosa pudica Linn, a massive local grass in Indonesia. The extract came from leaves, flowers and the mix. This result of this study will provide more references regarding the organic dye used as sensitizer for DSSC.

\section{Material and Methods}

\subsection{Natural dyes extraction}

The fresh leaves and flowers of Mimosa pudica Linn were dried. The dried raw materials were ground in the same weight proportion for leave, flower and mix samples. Then all samples extracted by maceration method by ethanol for 24 hours. The next step is evaporation of the solvent using the rotary evaporator.

\subsection{Fabrication of solar cells}

Indium-tin-oxide (ITO) glass which dimension of $0.7 \mathrm{~cm} \times 2 \mathrm{~cm} \times 2 \mathrm{~cm}$ and resistance 7 $\Omega-9 \Omega$ were first washed using a neutral cleaner. The resistance of ITO glass was measured to make sure that the $\mathrm{TiO}_{2}$ pasta placed in the right position. $\mathrm{TiO}_{2}$ paste is applied to the surface of the ITO glass by the doctor blade method within $1 \mathrm{~cm}^{2}$ area of glass. The glass with pasta of $\mathrm{TiO}_{2}$ then left about 10 minutes to dried. When pasta is completely dried, the next process was sintering in $400{ }^{\circ} \mathrm{C}$ for about 30 minutes. In this process, pasta color changed from white to brown and then white again. The last white color indicated that the $\mathrm{TiO}_{2}$ had been ready to absorb the dye.

The three samples of dyes were shaken by ultrasonic shaker before application. The sintered glass then immersed into dye of flowers sample and left for 24 hours. The same procedure was used for dye of leaves and the mix of leaves and flowers. The last process were the preparation of the conductive glass by using carbon.

\subsection{Measurement}

There are some measurement have been used in this work. UV-VIS (UV-2600 Shimadzu) was used to show the maximum absorption at which the dyes significantly absorb the sun rays. FTIR (Prestige-21 Shimadzu) was used to identify the functional groups of the chemical components of the dyes. SEM-EDX (Joe JSM-6510 LA) was used to provide the microsystem morphology of the $\mathrm{TiO}_{2}$ and dyes on ITO glass. Whereas, XRD (Rigaku Miniflex2) was used to show the diffraction and phase of the $\mathrm{TiO}_{2}$ which is used in this research. The last measurement are the photocurrent and voltage using digital multi-meter (UX-369C) under sun illuminated. A potentiometer is used to show the degradation of photocurrent and voltage of solar cell. In the same time, the incident of light power was measured by sunlight meter (Lx 1330B-Lux 200k). The efficiency of solar cell is given by

$$
\eta=\frac{I_{S C} V_{O C} F F}{P_{\text {in }}}
$$


Variables Isc, $\mathrm{V}_{\mathrm{oc}}, \mathrm{FF}$, and $P_{\text {in }}$ in equation (1) represent of photocurrent short-circuit, voltage open circuit, fill factor, power input respectively. The power input, $P_{i n}$, is number of incident photon which measure by sunlight meter. The fill factor was determined by

$$
F F=\frac{V_{\max } I_{\max }}{V_{o c} I_{s c}}
$$

Where $V_{\max }$, and $I_{\max }$ represent the voltage and current per unit area at the maximum output power point.

\section{Results and Discussion}

3.1 Absorption spectrum of dyes

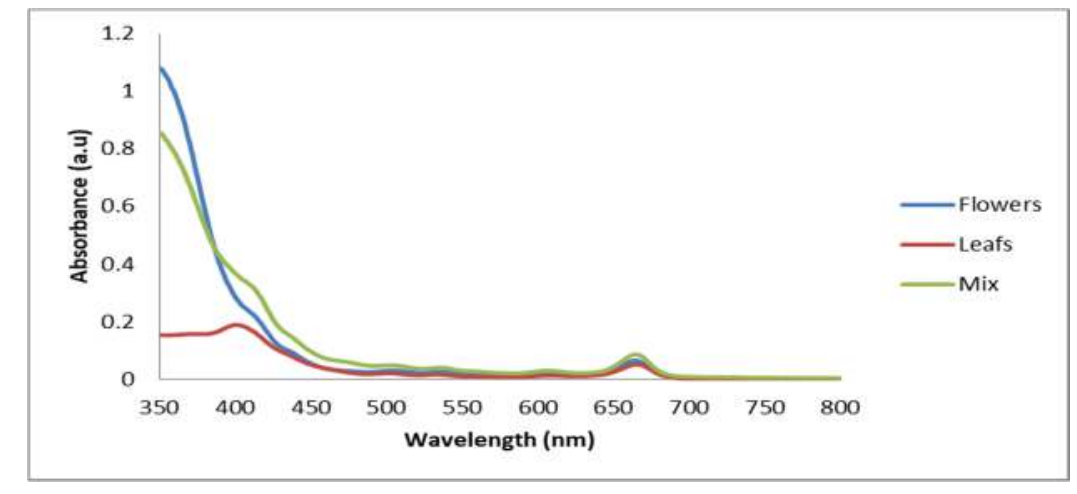

Figure 1. Absorption spectra of Mimosa pudica Linn dyes

Spectrum absorption in Figure 1, in general, illustrated that peaks of all dyes placed in quite similar value of wavelength, about $665 \mathrm{~nm}$. In deep observation, it can be found that each dye has four peaks in range wavelength $450 \mathrm{~nm}$ to $800 \mathrm{~nm}$. In detail, the peaks placed in $500 \mathrm{~nm}$, $545 \mathrm{~nm}, 600 \mathrm{~nm}$, and $665 \mathrm{~nm}$ respectively. The absorption spectra of the samples completely different from another research which utilized dye extracted from Sappan woods [12] and Caesalpinia Sappan heartwood [18]. However, this results shown better efficiencies than others in recent progress of DSSC [11].

$4 \quad \mathrm{TiO} 2 \mathrm{X}$-ray Diffraction 


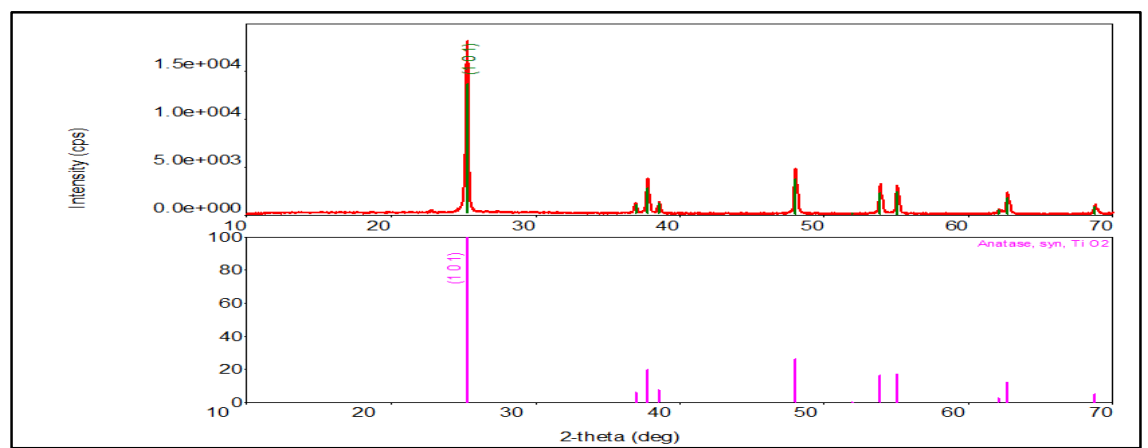

Figure 2. X-ray characteristics of Titanium di-oxide

Difraction of $\mathrm{TiO} 2$ in Figure 2 showed that the paste $\mathrm{TiO} 2$ which used in this research in anatase fase. As we know that, $\mathrm{TiO} 2$ have two fase; rutile fase and anatase fase. In terms of DSSC application, anatase fase is known have the least quality than another. It obviously will influence cells' efficiency.

\subsection{Photovoltaic Characteristics}

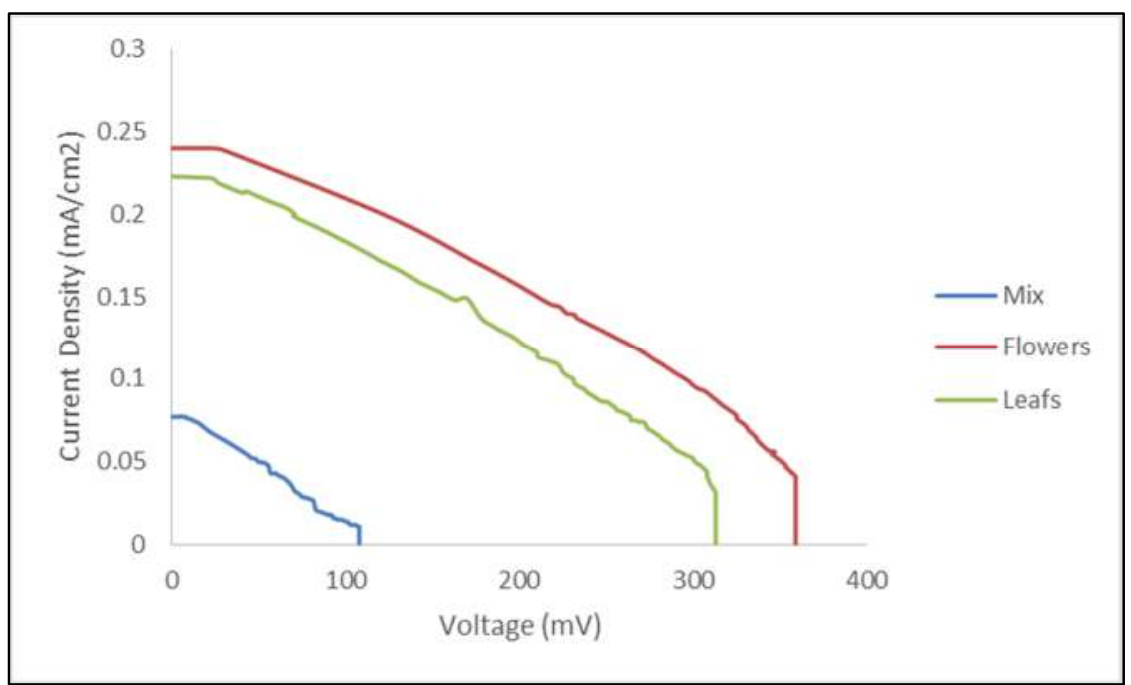

Figure 3. I-V curve of photovoltics

Figure 3 shows that the curve current density and voltage in each square area. The measurement were measured under the sun outdoor illuminated. It is clearly showed that DSSC which flowers dye gave a significant number of photocurrent and voltage. The maximum photocurrents are $0.24 \mathrm{~mA}$ and $313 \mathrm{mV}$ respectively. The similar path shows in DSSC with dye came from leaves but slightly slower than the flowers DSSC. The maximum photocurrent is $0.23 \mathrm{~mA}$ and the voltage is $313 \mathrm{mV}$. The solar cell which extract sample mix of flowers and leaves shows the most insignificant in harvesting solar energy to electricity. The maximum 
photocurrent and open circuit voltage are $0.07 \mathrm{~mA}$ and $108 \mathrm{mV}$. Therefore, although the I-V curve shows the highest and low DSSC from flowers, leaves and mix respectively, the fill factor (FF) shows vice versa. Characteristic of DSSC is showed in the table below,

Tabel 1. Efficiency of dye sensitized solar cells

\begin{tabular}{cccccc}
\hline Sample & $\mathrm{V}_{\mathrm{oc}}(\mathrm{V})$ & $\mathrm{J}_{\mathrm{sc}}(\mathrm{mA})$ & $\mathrm{FF}$ & $\mathrm{P}_{\text {in }}\left(\mathrm{mW} / \mathrm{cm}^{2}\right)$ & $\eta(\%)$ \\
\hline Flowers & 0.35 & 0.24 & 0.37 & 8.78 & 0.16 \\
Leafs & 0.31 & 0.22 & 0.36 & 8.78 & 0.12 \\
Mix & 0.11 & 0.07 & 0.54 & 8.78 & 0.01 \\
\hline
\end{tabular}

Table 1, showed that the maximum PCE efficiency given by DSSC flowers extract; 0.16 $\%$ with fill factor 0.37 . DSSC with leaves extract show the second position with efficiency 0.12 $\%$ with fill factor 0.36 , and the lowest efficiency given by the mix of the extract, $0.01 \%$ but has highest fill factor 0.57 .
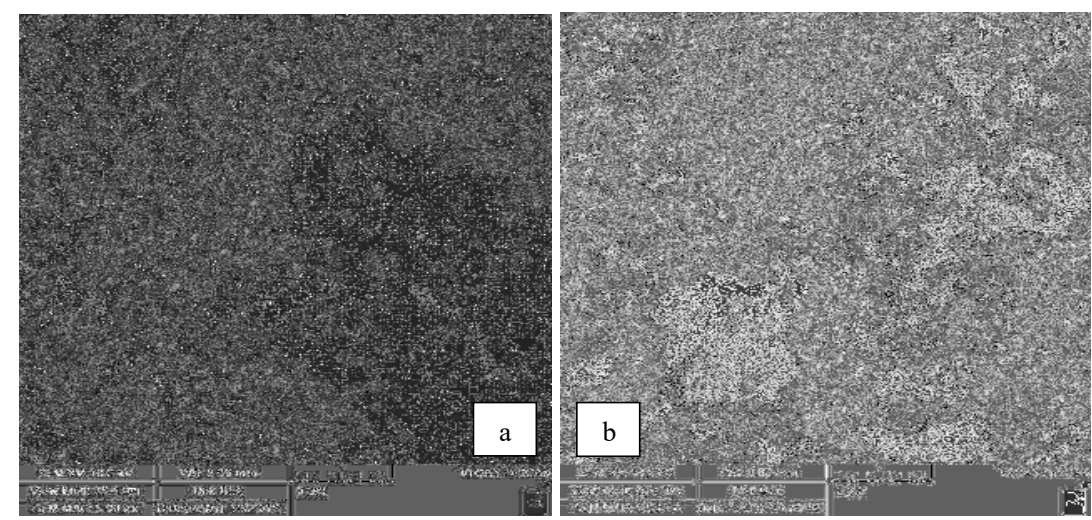

Figure 4. SEM morfologi of photovoltaics, a) leaves and b) flowers.

It can be seen from the SEM characterization that the $\mathrm{TiO}_{2}$ paste which sensitized by leaves and flower extract seem to have gaps (Fig. 4). Flowers extract-sensitized cells (Fig. 4 b) show more gaps than the leaves (Fig. 4a). These gaps may contribute to the result of this research. It is assumed that the I-V curve will show good performance if the DSSC has not the gaps. This is the main attention in our future research.

\section{Conclusion}

A new study of solar cell base on dye-sensitized has been presented. The extract dyes of Mimosa pudica Linn containing of three types; flowers, leaves, and mix. The result shows that DSSC with flower dye has a significant I-V curve and has efficiency of $0.16 \%$. Leaves DSSC had slightly lower efficiency, $0.12 \%$, and the mix only showed $0.01 \%$. 


\section{Acknowledgments}

This work was sponsored by the research grant from the Ministry of Religious Affair, LP2M UIN Alauddin Makassar under contract number: 581.A/LP2M-UIN/VI/2018.

\section{References}

[1] V. D. K.L.Chopra, P.D. Paulson, “Thin Film Solar Cell - An Overview.pdf,” Prog. Photovoltaics Res. Appl., vol. 12, no. 2-3, pp. 69-92, 2004.

[2] B. O'Regan and M. Grätzel, "A low-cost, high-efficiency solar cell based on dyesensitized colloidal TiO2 films," Nature, vol. 353, no. 6346, pp. 737-740, Oct. 1991.

[3] M. A. Green et al., "Solar cell efficiency tables (version 50)," Prog. Photovoltaics Res. Appl., vol. 25, no. 7, pp. 668-676, 2017.

[4] Y. Chiba, A. Islam, Y. Watanabe, R. Komiya, N. Koide, and L. Han, "Dye-sensitized solar cells with conversion efficiency of 11.1\%," Japanese J. Appl. Physics, Part 2 Lett., vol. 45, no. 24-28, pp. 638-640, 2006.

[5] R. Humphry-Baker et al., "Dye-sensitized solar cells with $13 \%$ efficiency achieved through the molecular engineering of porphyrin sensitizers," Nat. Chem., vol. 6, no. 3, pp. 242-247, 2014.

[6] G. Wang, W. Xiao, and J. Yu, "High-efficiency dye-sensitized solar cells based on electrospun TiO2 multi-layered composite film photoanodes," Energy, vol. 86, pp. 196203, 2015.

[7] A. K. K. Kyaw et al., "Dye-sensitized solar cell with a pair of carbon-based electrodes," J. Phys. D. Appl. Phys., vol. 45, no. 16, 2012.

[8] M. Hosseinnezhad, K. Gharanjig, S. Moradian, and M. R. Saeb, "In quest of power conversion efficiency in nature-inspired dye-sensitized solar cells: Individual, cosensitized or tandem configuration?," Energy, vol. 134, pp. 864-870, 2017.

[9] X. Liu, C. Zhang, S. Liu, and Y. Xiong, "Efficiency enhancement of DSSC by alternating TiO2 active layer," Optik (Stuttg)., vol. 160, pp. 277-282, 2018.

[10] R. Magaraphan and J. Joothamongkhon, "Performance of Dye-Sensitized Solar Cells Using ZnO-Natural Dyes from Sappan Wood, Noni Leaves, Safflower and Black Rice," Adv. Mater. Res., vol. 658, pp. 25-29, 2013.

[11] N. T. R. N. Kumara, A. Lim, C. M. Lim, M. I. Petra, and P. Ekanayake, "Recent progress and utilization of natural pigments in dye sensitized solar cells: A review," Renew. Sustain. Energy Rev., vol. 78, no. April, pp. 301-317, 2017.

[12] S. Landuma, D. A. Haryanto, and A. Purwanto, "Application of sappan wood (Caesalpinia sappan linn) as sensitizer for dye-sensitized solar cell (DSSC)," AIP Conf. Proc., vol. 1586, no. 2014, pp. 109-112, 2014.

[13] M. M. Noor et al., “ TiO 2 /Chitosan- NH 4 I(+I 2 ) -BMII-Based Dye-Sensitized Solar Cells with Anthocyanin Dyes Extracted from Black Rice and Red Cabbage ," Int. J. Photoenergy, vol. 2011, pp. 1-11, 2011.

[14] Y.-J. Wang, J. Patindol, D. Gealy, A. Flowers, and M.-I. Kuo, "Comparison of Physicochemical Properties and Starch Structure of Red Rice and Cultivated Rice," $J$. Agric. Food Chem., vol. 54, no. 7, pp. 2712-2718, 2006.

[15] Z. Ulma, E. Rahayuningsih, and T. D. Wahyuningsih, "Methylation of Brazilein on Secang (Caesalpinia sappan Linn) Wood Extract for Maintain Color Stability to the Changes of pH," IOP Conf. Ser. Mater. Sci. Eng., vol. 299, no. 1, 2018. 
[16] Khairurrijal, E. Yuliza, M. Rosi, A. Mikrajuddin, D. Y. Rahman, and S. Saehana, "Enhancement Performance of Dye-Sensitized Solar Cells from Black Rice as Dye and Black Ink as Counter Electrode with Inserting Copper on the Space between $\mathrm{TiO}_{2}$ Particle's by Using Electroplating Method," Mater. Sci. Forum, vol. 737, no. February, pp. 85-92, 2013.

[17] U. M. Fadli, A. B. Prasada, Cari, and A. Supriyanto, "The effect of Cu doping into Oriza sativa L. indica dye as photosensitizer for dye sensitized solar cell (DSSC)," J. Phys. Conf. Ser., vol. 776, no. 1, 2016.

[18] S. Ananth, P. Vivek, G. Saravana Kumar, and P. Murugakoothan, "Performance of Caesalpinia sappan heartwood extract as photo sensitizer for dye sensitized solar cells," Spectrochim. Acta - Part A Mol. Biomol. Spectrosc., vol. 137, pp. 345-350, 2015.

[19] A. B. Prasada, U. M. Fadli, Cari, and A. Supriyanto, "Dye Oriza sativa glutinosa doped Fe as a active element of Dye Sensitized Solar Cell (DSSC)," J. Phys. Conf. Ser., vol. 776, no. 1, 2016.

[20] A. O. Boyo, T. J. Abodunrin, T. Adebayo, O. Obafemi, and R. Jimoh, "The Effect of Electrolyte on Dye Sensitized Solar Cells Using Natural Dye from Mango (\&lt;i\&gt;M. indica\&lt;/i\&gt; L.) Leaf as Sensitizer," Adv. Mater. Phys. Chem., vol. 05, no. 06, pp. 205-213, 2015.

[21] T. A. Ruhane et al., "Impact of photo electrode thickness and annealing temperature on natural dye sensitized solar cell," Sustain. Energy Technol. Assessments, vol. 20, pp. 72-77, 2017.

[22] A. S. Shikoh, Z. Ahmad, F. Touati, R. A. Shakoor, and S. A. Al-Muhtaseb, "Optimization of ITO glass/TiO2 based DSSC photo-anodes through electrophoretic deposition and sintering techniques," Ceram. Int., vol. 43, no. 13, pp. 10540-10545, 2017. 